\title{
BRCD1 Gene
}

National Cancer Institute

\section{Source}

National Cancer Institute. BRCD1 Gene. NCI Thesaurus. Code C20775.

Human BRCD1 gene is located within chromosome 13 and the size of this phenotypic locus is not reported. This phenotype-only gene has not been linked to a known protein product. Mutation of this locus is associated with radioresistance of several types of cancers; including, retinoblastoma, mesenchymal tumors and ductal carcinoma. 